\title{
Caring for the Tribe: From Addiction to Zen
}

\section{David Loxterkamp, MD}

Seaport Community Health Center, Belfast, Maine
Conflicts of interest: author reports none.

\section{CORRESPONDING AUTHOR}

David Loxterkamp, MD

Seaport Community Health Center

53 Schoodic Drive

Belfast, ME 04915

david.loxterkamp@gmail.com

\begin{abstract}
The culture of medicine is rapidly changing. The majority of primary care physicians are now employed, and the decisions that govern us are made farther and farther from the point of care. Our sense of well-being is threatened less by the demands of clinical practice than it is by the emptiness of our job: we have forgotten who we are working for, or working with, or why we are working at all. The solution lies in creating the kind of practice environment that we advocate for in each of our patients' lives.
\end{abstract}

Ann Fam Med 2017;15:578-580. https://doi.org/10.1370/afm.2151.

Social resilience is an even better predictor of trauma recovery than the level of resilience of the person himself. - Sebastian Junger, Tribe

E arlier this year, 2 younger colleagues of mine left the practice. Their parting was especially painful because I had recruited them, and because they were quickly regarded as among the brightest and most respected in our group. For a rural family practice such as ours, such losses are not easily absorbed. The financial costs are enormous-by some estimates between $\$ 250,000.00$ and a million dollars, ${ }^{1}$ when recruitment fees, lost revenue, and retraining are taken into account. And there is little chance of quickly replacing young family physicians.

The hardest part has not been caring for their patients or covering their call, but learning from their departure. Why did they leave the "family," and why did I decide to stay?

Four years ago we sold our practice to a federally qualified health center (FQHC). The usual factors went into that decision: aging owners, the increasing complexity of insurers' demands; disinterest among our younger colleagues for an administrative role or "buying-in" to the practice. A year later we moved into a new facility that doubled the size of our staff and tripled the office space. The new floor plan included a pharmacy, physical therapy department, and care management office, and allowed us to expand behavioral health services. We qualified for NCQA Level III status. Although we had given up obstetrical and hospital privileges a few years earlier, we imagined ourselves as the new breed of full-service health center, meeting the non-medical needs of our patients through team-based care.

But we forgot about the law of unintended consequences. The new administrative offices are an hour's drive away (in good weather). Decisions in our organization are seldom made by those who implement them, and often without their input. As with many large networks, communication trickles through the proper channels. The growth of our health center has led to a loss of intimacy; we no longer know, let alone greet, each other by our first names. There is more emphasis on the policy than the person for whom it was created. Of course, medicine is a business, but business people forget who does the real work or what rewards them. Not (only) money. Not (only) a yearly barbecue or certificate of recognition. No matter how many virtuous employees are hired (and I am surrounded by them), an emphasis on efficiency and productivity will bury their better instincts, our deepest humanity. Sadly, when that is gone, there is little to sustain us through the drudgery. 
It has been a dozen years now since I met my first patient with heroin addiction. She presented to the emergency department in acute withdrawal, or what I had misdiagnosed as intractable gastroenteritis. But I had little to offer her for her addiction: no formal training, no specific treatment; ${ }_{i}$ no knowledge of the community's resources $_{i}$ just a desire to help. Within a year, a colleague and I had earned our waiver to prescribe buprenorphine, a partial $m u$ receptor agonist that had just been approved for outpatient treatment of opioid use disorder. Over time we cobbled together a recovery program that integrated behavioral therapy, care management, and medication-assisted treatment in a group setting.

We listened closely to what patients told us they needed. They needed jobs, housing, insurance, legal help, and skills in nonviolent communication, goalsetting, and impulse control. For most of them, recovery meant a sharp break from their prior community of users, dealers, and petty larcenists. They needed a safe place to gather and a community committed to sobriety. What we required of them was honesty, accountability, and the willingness to change. In return, we gave them a prescription, but also our time, attention, and a belief in their future.

Working in addiction medicine has forced me to question the nature of my job. The basic needs of an addict are the same as any other individual: to feel useful and connected. And that is precisely what addiction, poverty, mental illness, disability, chronic illness, and aging deplete. Sometimes it falls to the primary care doctor to help restore the lost connections of those who are marginalized. While our first priority is the illness, we know that recovery often requires adequate health insurance, safe shelter, reliable transportation, affordable nutrition, visitors to the home, and a job within their reach. Doctors work at their best—alive and fulfilledwhen we address the whole needs of our patients and see their problems, their lives, as like our own. The tools at our disposal-at very least, and in every encounterare conversation, friendship, and hope.

And here is what I must say to you: the basic needs of the doctor and patient are identical, the effects of unrelenting stress the same. More than one-third of active physicians report symptoms of burnout. ${ }^{2-4}$ Even under the best of circumstances, our patients sicken and die. Under the worst, we contribute to their woes. Much of our decision making occurs under a cloud of uncertainty, yet the consequences are no less serious, the social expectations no less exacting. Increasingly, we devote our time to an ungrateful and demanding computer interface, and ignore the very people whose handshake, smile, stories of courage, and acts of kindness have real power to restore us.
We work in a human desert with little shade from the heat. We've adjusted to our new role as checklist accountant and master machinist, working at the top of our license. We regard the office as a job site, the paycheck as sufficient reward, our work station as one stop along an assembly line. Our distinct and separate roles often prevent us from developing close relationships with our patients or seeing the outcome of their care. We are the poster children for burnout: moving parts of a well-oiled machine, geared for production.

Sebastian Junger's new book, Tribe: On Homecoming and Belonging provides a blueprint for our revival. ${ }^{5}$ He explores the time in America's western expansion when "a surprising number of Americans-mostly men-wound up joining Indian society rather than staying in their own... and the opposite almost never happened." What attracted them was the high degree of freedom, egalitarianism, loyalty, connection, and sacrifice they found in tribal culture-and their absence in the life they left behind.

As a war correspondent, Junger also notes the high rate of chronic post-traumatic stress disorder (PTSD) among soldiers returning from the wars in Iraq and Afghanistan. Roughly one-half of the soldiers were applying for permanent PTSD disability, compared with less than $1 \%$ of Israeli soldiers for whom military service was universally required, socially embraced, and visible in daily life. Again, what to make of this? The difference between the American and Israeli soldier was the community they came home to. He concluded that social resilience is even a better predictor of trauma recovery than the level of resilience of the individual.

How would tribal values influence the workflow of a busy practice or restore the strength of its resilience? Those in authority could, first of all, see the practice as the unit of care-not as separate teams or players ranked by license. We could give every employee the authority to break protocol, individualize solutions, apply their ingenuity, and be flexible with their time. We could share the sacrifices of the office equitably, such as the call schedule, extended hours, or charitable activities chosen by the practice as a whole. We could provide regular, specific feedback on job performance and include everyone's input on decisions that directly affect them. We could sponsor moments of restoration during the regular workday, including mindful meditation or a group walkabout. And at very least, we could begin to meet, talk, set goals, solve problems, and celebrate together. That would be a start.

It's hard to know exactly why my colleagues left the practice, or if anything could have been done to "save" them. That they failed to meet management's expectations is highly probable; that management failed to meet 
theirs is self-evident. More than anything else, it represents a failure of community in the tribal sense.

I remain committed to an ideal: where self-sacrifice is seen as a sign of loyalty and loyalty as a call to service; where it is the doctor's duty to create an individualized treatment plan and the patient's right to refuse $\mathrm{it}_{\text {; }}$ where the genius loci compels us to work on behalf of the universal need for connection and sense of purpose. And I trust that I am not alone.

Let's not fear the exception. Let's always remember who we work for, and what part of the job provides the best return on our investment. The desire for belonging can be a centrifugal force, a widening arc. Corporate expansion is no excuse for losing even 1 member of the tribe. "The ultimate betrayal of society," Junger assures us, "isn't acting competitively_that should be encouraged-but predicating your power on the excommunication of others from the group."

The human impulse to help others is a resilient force. And its traction within the medical profession guarantees our ability to recruit the brightest minds and biggest hearts of every generation. But the work is hard and exacts a toll on those who choose it. We must use our authority, empathy, and courage to extend the benevolence of community to every neighbor and neighborhood we touch, especially our own.

To read or post commentaries in response to this article, see it online at http://www.AnnFamMed.org/content/15/6/578.

Key words: humanism; burnout; group practice; medical professionalism

Submitted December 21, 2016; submitted, revised, March 21, 2017; accepted May 11, 2017.

\section{References}

1. Misra-Hebert AD, Kay R, Stoller JK. A review of physician turnover: rates, causes, and consequences. Am J Med Qual. 2004;19(2):56-66.

2. Goitein L, O'Malley PG, Redberg RF. Physician work environment and well-being: a call for papers. JAMA Intern Med. 2017;177(2): 164-165.

3. Panagioti M, Panagopoulou E, Bower $P$, et al. Controlled interventions to reduce burnout in physicians: a systematic review and meta-analysis. JAMA Intern Med. 2017;177(2):195-205.

4. Wallace JE, Lemaire JB, Ghali WA. Physician wellness: a missing quality indicator. Lancet. 2009;374(9702):1714-1721.

5. Junger S. Tribe: On Homecoming and Belonging. New York, NY: Twelve/Hatchette Book Group; 2016. 